\title{
Ohio River Backwater Flood-Inundation Maps for the Saline and Wabash Rivers in Southern Illinois
}

Scientific Investigations Report 2012-5212 Version 1.1, September 2014 
Cover. View of flooding in Old Shawneetown from the Ohio River taken from the Route 13 bridge on May 10, 2011. (Photograph by the U.S. Geological Survey.) 


\section{Ohio River Backwater Flood-Inundation Maps for the Saline and Wabash Rivers in Southern Illinois}

By Elizabeth A. Murphy, Jennifer B. Sharpe, and David T. Soong

Scientific Investigations Report 2012-5212

Version 1.1, September 2014 


\title{
U.S. Department of the Interior \\ KEN SALAZAR, Secretary \\ U.S. Geological Survey \\ Marcia K. McNutt, Director
}

\author{
U.S. Geological Survey, Reston, Virginia: 2012 \\ Revised: September 2014
}

\begin{abstract}
For more information on the USGS - the Federal source for science about the Earth, its natural and living resources, natural hazards, and the environment, visit http://www.usgs.gov or call 1-888-ASK-USGS.

For an overview of USGS information products, including maps, imagery, and publications, visit http://www.usgs.gov/pubprod

To order this and other USGS information products, visit http://store.usgs.gov
\end{abstract}

Any use of trade, firm, or product names is for descriptive purposes only and does not imply endorsement by the U.S. Government.

Although this information product, for the most part, is in the public domain, it also may contain copyrighted materials as noted in the text. Permission to reproduce copyrighted items must be secured from the copyright owner.

Suggested citation:

Murphy, E.A., Sharpe, J.B., and Soong, D.T., 2012, Ohio River backwater flood-inundation maps for the Saline and Wabash Rivers in southern Illinois (ver. 1.1, September 2014): U.S. Geological Survey Scientific Investigations Report 2012-5212, 20 p., http://pubs.usgs.gov/sir/2012/5212. 


\section{Contents}

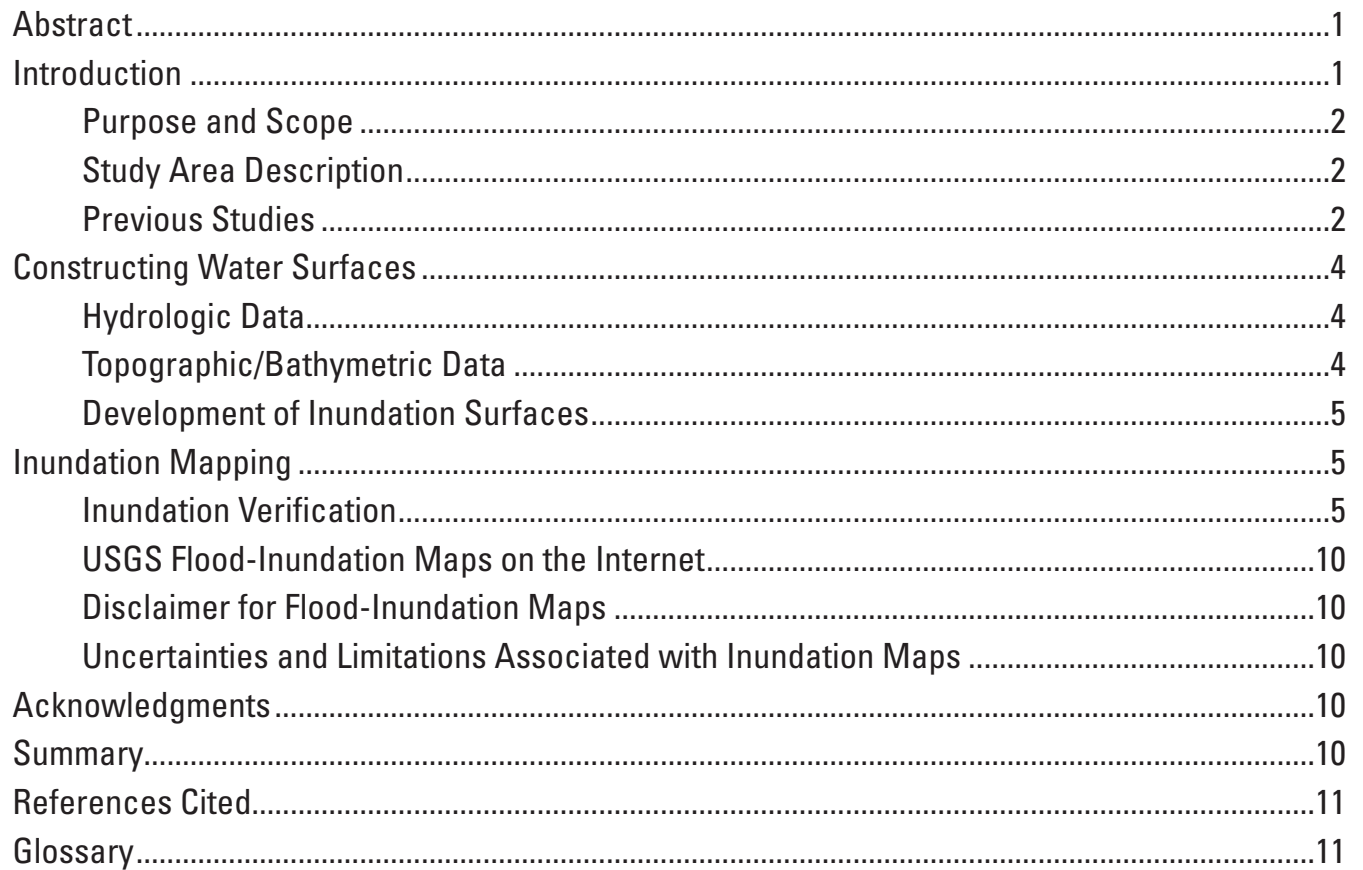

\section{Figures}

1. Map showing location of study area for the Saline and Wabash Rivers study, Illinois, and location of U.S. Geological Survey streamgages and National Weather Service forecast point............................................................................

2. Map showing the grouped Hydrologic Unit Code (HUC-12) basins with common water-surface elevations assigned for inundation-surface generation.............6

3. Maps showing generated water-surface elevations as compared to satellite imagery of flooding.

\section{Tables}

1. U.S. Geological Survey streamgage information for the Ohio River at Old Shawneetown, Illinois-Kentucky, and the Middle Fork Saline River near Harrisburg, Illinois

2. Relative elevations of the Ohio River at Old Shawneetown USGS streamgage, Ohio-Saline confluence, and Ohio-Wabash confluence 


\section{Map Sheets}

Sheets 1-8. Flood-inundation maps for the Saline and Wabash Rivers, Illinois, corresponding to USGS streamgage Ohio River at Old Shawneetown, Illinois-Kentucky (station 03381700) for gage height of:

1. 31 feet.

2. 36 feet.

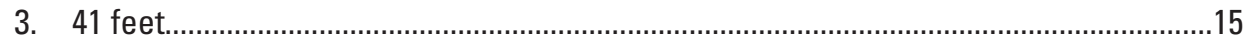

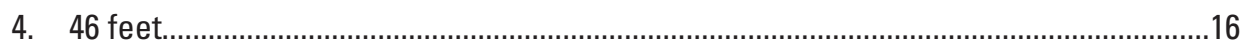

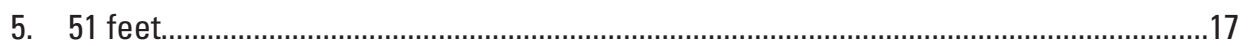

6. 56 feet. 18

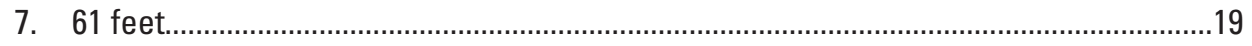

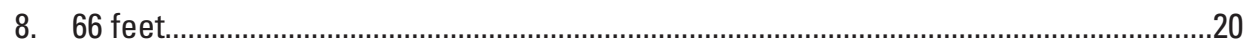

(Map sheets are also available for downloading separately at $h$ ttp://pubs.usgs.gov/sir/2012/5212/.)

\section{Conversion Factors}

\begin{tabular}{lcl}
\hline \multicolumn{1}{c}{ Multiply } & By & \multicolumn{1}{c}{ To obtain } \\
\hline & Length & \\
\hline inch (in) & 25.4 & millimeter $(\mathrm{mm})$ \\
foot $(\mathrm{ft})$ & 0.3048 & meter $(\mathrm{m})$ \\
mile $(\mathrm{mi})$ & 1.609 & kilometer $(\mathrm{km})$ \\
\hline & Area & \\
\hline square foot $\left(\mathrm{ft}^{2}\right)$ & 0.09290 & square meter $\left(\mathrm{m}^{2}\right)$ \\
square mile $\left(\mathrm{mi}^{2}\right)$ & 2.590 & square kilometer $\left(\mathrm{km}^{2}\right)$ \\
\hline & Flow rate & \\
\hline cubic foot per second $\left(\mathrm{ft}^{3} / \mathrm{s}\right)$ & 0.02832 & cubic meter per second $\left(\mathrm{m}^{3} / \mathrm{s}\right)$ \\
\hline & Hydraulic gradient & \\
\hline foot per mile $(\mathrm{ft} / \mathrm{mi})$ & 0.1894 & meter per kilometer $(\mathrm{m} / \mathrm{km})$ \\
\hline
\end{tabular}

Vertical coordinate information is referenced to the North American Vertical Datum of 1988 (NAVD 88).

Horizontal coordinate information is referenced to the North American Datum of 1983 (NAD 83).

Elevation, as used in this report, refers to distance above the vertical datum. 


\title{
Ohio River Backwater Flood-Inundation Maps for the Saline and Wabash Rivers in Southern Illinois
}

\author{
By Elizabeth A. Murphy, Jennifer B. Sharpe, and David T. Soong
}

\section{Abstract}

Digital flood-inundation maps for the Saline and Wabash Rivers referenced to elevations on the Ohio River in southern Illinois were created by the U.S. Geological Survey (USGS). The inundation maps, accessible through the USGS Flood Inundation Mapping Science Web site at http://water.usgs.gov/ osw/flood_inundation/, depict estimates of the areal extent of flooding corresponding to selected water levels (gage heights) at the USGS streamgage at Ohio River at Old Shawneetown, Illinois-Kentucky (station number 03381700). Current gage height and flow conditions at this USGS streamgage may be obtained on the Internet at http://waterdata.usgs.gov/usa/nwis/ $u v ? 03381700$. In addition, this streamgage is incorporated into the Advanced Hydrologic Prediction Service (AHPS) flood warning system (http://water.weather.gov/ahps/) by the National Weather Service (NWS). The NWS forecasts flood hydrographs at many places that are often co-located at USGS streamgages. That NWS forecasted peak-stage information, also shown on the Ohio River at Old Shawneetown inundation Web site, may be used in conjunction with the maps developed in this study to show predicted areas of flood inundation.

In this study, eight water-surface elevations were mapped at 5-foot (ft) intervals referenced to the streamgage datum ranging from just above the NWS Action Stage $(31 \mathrm{ft})$ to above the maximum historical gage height ( $66 \mathrm{ft})$. The elevations of the water surfaces were compared to a Digital Elevation Model (DEM) by using a Geographic Information System (GIS) in order to delineate the area flooded at each water level.

These maps, along with information on the Internet regarding current gage heights from USGS streamgages and forecasted stream stages from the NWS, provide emergency management personnel and residents with information that is critical for flood response activities such as evacuations and road closures, as well as for post-flood recovery efforts.

\section{Introduction}

Saline County, with an estimated 2010 population of 24,913 (U.S. Census Bureau, 2012a), and Gallatin County, with an estimated 2010 population of 5,528 (U.S. Census Bureau, 2012b), are in southern Illinois (fig 1). Parts of Saline and Gallatin Counties have experienced severe flooding numerous times, most notably in March 2008, May 2009, and MarchMay 2011. Damage from the March 2008 flood was estimated at \$16.8 million in Harrisburg (Federal Emergency Management Agency, 2011a). Saline and Gallatin Counties were designated counties in the Federal Emergency Management Agency (FEMA) disaster declarations in July 2009 (DR-1850) and June 2011 (DR-1991) (Federal Emergency Management Agency, 2009, 2011c). Spring 2011 brought record flooding to much of southern Illinois, including both the Mississippi and Ohio Rivers. Land use along flood plains in the study area is mostly agricultural, with scattered residential and commercial structures.

Prior to this study, county and municipal officials relied on several information sources to make decisions on how to best alert the public about impending flooding and to mitigate flood damages. One source is the FEMA Flood Insurance Study (FIS) for Saline County, Illinois, and Incorporated Areas, dated December 16, 2011 (Federal Emergency Management Agency, 2011a), and for Gallatin County, Illinois, and Incorporated Areas, dated December 2, 2011 (Federal Emergency Management Agency, 2011b). A second source of information has been the U.S. Geological Survey (USGS) streamgages Ohio River at Old Shawneetown, Illinois-Kentucky (Ill.-Ky.) (station no. 03381700) and Middle Fork Saline River near Harrisburg, Ill. (station no. 03382200), from which current or historical gage heights can be obtained. A third source has been the National Weather Service (NWS) forecast of peak stage (gage height) at the USGS Old Shawneetown streamgage through the Advanced Hydrologic Prediction Service (AHPS) site. Although USGS 
current stage and NWS forecast stage information is useful for residents in the immediate vicinity of a streamgage, it is of limited use to residents farther upstream or downstream because the water-surface elevation is not constant along the entire stream channel. Also, FEMA and State emergency management mitigation teams or property owners typically lack information related to how deep the water is at locations other than near USGS streamgage or NWS flood-forecast points.

\section{Purpose and Scope}

The purpose of this report is to (1) describe the development of a series of estimated flood-inundation maps for the Saline and Wabash Rivers based on gage heights on the Ohio River in southern Illinois, and (2) provide users with a library of flood-inundation maps that correspond to water levels referenced to the gage heights at the USGS streamgage on the Ohio River at Old Shawneetown, Ill.-Ky., ranging from $31 \mathrm{ft}$ to $66 \mathrm{ft}$. This report is a description of the maps and other flood information available on the USGS Flood Inundation Mapping Science Web site at http://water.usgs.gov/osw/ flood_inundation/.

\section{Study Area Description}

The study area is in southern Illinois (fig. 1) and includes parts of the Saline and Wabash River systems. The northern part of the study area is in the Mt. Vernon Hill Country of the Till Plains section of the Central Lowland physiographic province, and the southern part is in the Shawnee Hills section of the Interior Low Plateaus physiographic province (Illinois State Geological Survey, 2012). The drainage area is $225 \mathrm{mi}^{2}$ at the Middle Fork Saline River near Harrisburg, Ill. (03382200), streamgage (U.S. Geological Survey, 2012). The Middle Fork Saline River is a tributary of the Ohio River with the confluence at Ohio River mile 867.4, about 9.5 mi downstream from the Ohio River at Old Shawneetown streamgage. Flooding on the Saline River system is strongly influenced by flooding on the Ohio River because of the flat topography at the confluence and along the Saline River. This topography causes the majority of flooding on the Saline River to be from Ohio River water flowing up the Saline River rather than from local runoff. The Saline River also receives overland flow from the Wabash River when it floods (fig. 1). The Wabash River is another tributary of the Ohio River that joins the Ohio River upstream of the Saline River confluence at Ohio River mile 848.8. Contributions from the Ohio and Wabash Rivers and local runoff make flooding of the Saline River a hydraulically complex problem.
The Saline River headwaters originate in adjacent Franklin, Williamson, and Hamilton Counties, and the river flows generally east-southeast before entering the study area. The study reach is approximately $33 \mathrm{mi}$ long, the top-of-bank channel width ranges from 60 to $185 \mathrm{ft}$, and the average channel slope is $0.27 \mathrm{ft} / \mathrm{mi}$. The land use along the study reach is a mix of agricultural, forested, and rural residential land. The main channel within the study reach has seven major road crossings.

\section{Previous Studies}

The current FISs for Saline County, Illinois, and Incorporated Areas, dated December 16, 2011(Federal Emergency Management Agency, 2011a), and Gallatin County, Illinois, and Incorporated Areas, dated December 2, 2011 (Federal Emergency Management Agency, 2011b), do not include any information on detailed hydrologic or hydraulic modeling of the Saline River. The Saline County FIS states that the Base Flood Elevation on the Middle Fork Saline River is controlled by backwater from the Saline River, which is in turn controlled by backwater flooding from the Ohio River. No profile or floodway for the Middle Fork Saline River is included in the Saline County FIS report. The flood-plain boundaries for the Saline River in the FIS report were delineated by using backwater from the Ohio River (Federal Emergency Management Agency, 2011a). The Gallatin County FIS states that the hydraulic behavior of the Wabash River is dominated by the Ohio River for 25 mi upstream of the confluence and that the Saline and North Fork Saline Rivers are controlled by backwater from the Ohio River. For the Saline River, the Saline County FIS states that the 1-percent annual exceedance probability flood water-surface elevation is $366.6 \mathrm{ft}$ and the 0.2 -percent annual exceedance probability flood watersurface elevation is $371.6 \mathrm{ft}$ at the confluence with the Ohio River (Federal Emergency Management Agency, 2011a). For the Wabash River, the Gallatin County FIS states that the 1-percent annual exceedance probability flood water-surface elevation is $368.5 \mathrm{ft}$ and the 0.2 -percent annual exceedance probability flood water-surface elevation is $373.2 \mathrm{ft}$ at the confluence with the Ohio River (Federal Emergency Management Agency, 2011b).

The historical record gage height at Ohio River at Old Shawneetown, Ill.-Ky., was reported to be $65.64 \mathrm{ft}$ on January 30, 1937, according to the National Weather Service (2012). The record gage height, corresponding to a water-surface elevation of $374.7 \mathrm{ft}$, was used to determine the upper bound of the mapping range. 


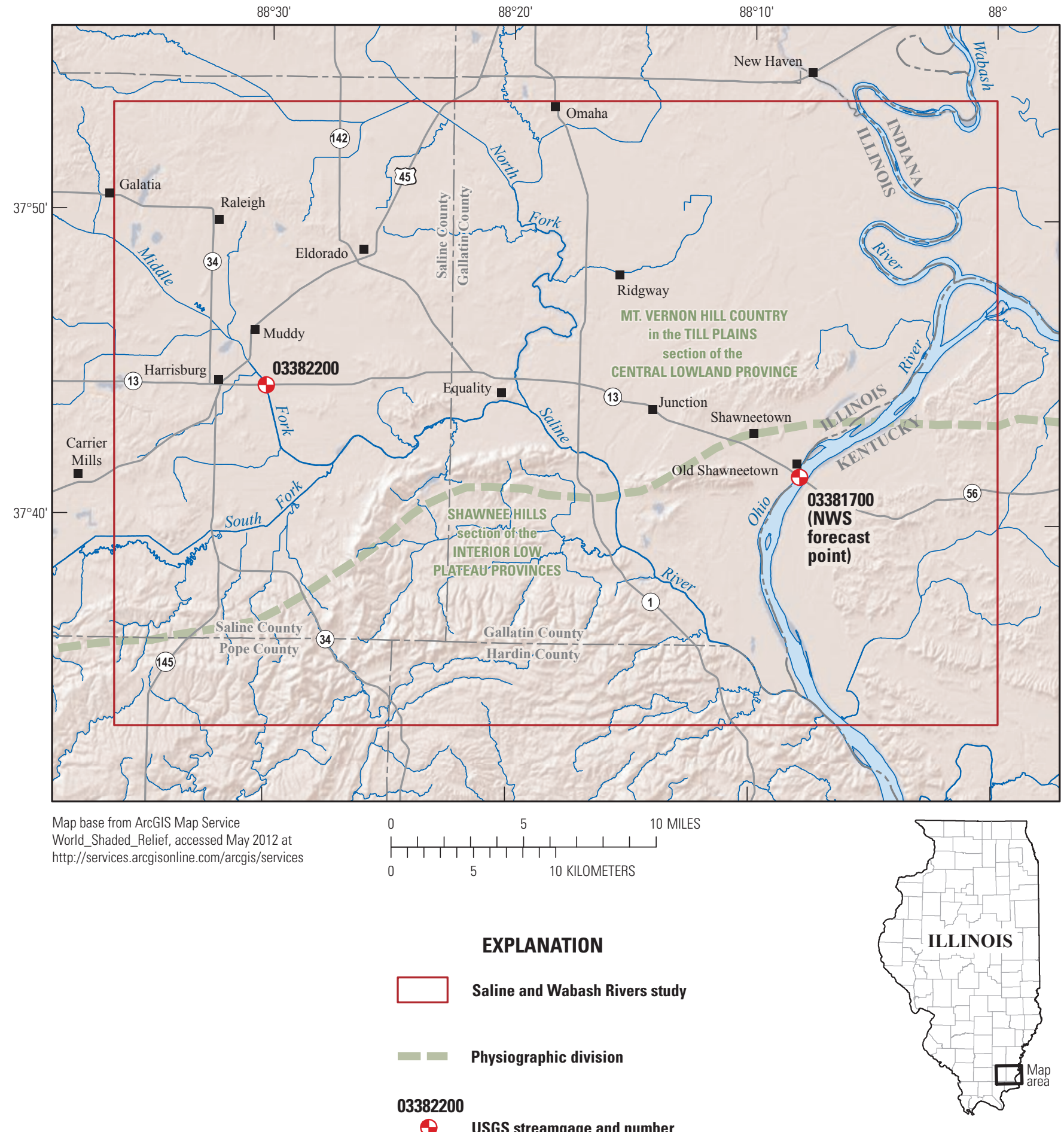

Figure 1. Map showing location of study area for the Saline and Wabash Rivers study, Illinois, and location of U.S. Geological Survey streamgages and National Weather Service forecast point. 


\section{Constructing Water Surfaces}

The water surfaces used to produce the eight floodinundation maps for this study were estimated by using water-surface elevations equivalent to the elevations along the Ohio River. This method was chosen because of a lack of hydrologic or hydraulic modeling for the study area and a history of backwater flooding from the Ohio River (Federal Emergency Management Agency, 2011a). Additionally, an analysis of the historical streamgage record on the Middle Fork Saline River near Harrisburg, Ill. (03382200), revealed that the Harrisburg streamgage would be in backwater from the Ohio River starting at a stage of $26 \mathrm{ft}$ at the streamgage at Old Shawneetown (Marvin L. Harris, U.S. Geological Survey, written commun., January 18, 2012). The extent of the influence of the Ohio River on the Middle Fork Saline River water-surface elevations means that a reliable relation between stage and discharge cannot be established at the Harrisburg streamgage. Determining the discharge at the Middle Fork Saline River near Harrisburg streamgage is also complicated by a non-unique relation between stage and discharge (Marvin L. Harris, U.S. Geological Survey, written commun., January 18, 2012). This non-uniqueness would make simulation of the Middle Fork Saline River with a one-dimensional, steady-state hydraulic model unrealistic. A one-dimensional, unsteadyflow model would also not capture the complexity of the flow because flow recirculation near the streamgage means that the flow direction must be described in two or three dimensions, not one (Marvin L. Harris, U.S. Geological Survey, written commun., January 18, 2012). A two-dimensional hydraulic model could be used for the system, but development of such a model would be prohibitively expensive. Considering these factors, generating water surfaces from Ohio River water-surface elevations was determined to give a reasonable estimate of the inundation surfaces.

\section{Hydrologic Data}

Hydrologic data in the study area were from the two previously mentioned streamgages (fig. 1; table 1). The Ohio River at Old Shawneetown, Ill.-Ky., streamgage was installed in January 2002 and has been recording discharge and water levels (gage height) continuously since installation. The Middle Fork Saline River near Harrisburg, Ill., streamgage was installed in August 2011 and has been recording water levels (gage heights) continuously since installation. This streamgage was also operated during October 1922-September 1932. The water-surface elevations from the Shawneetown streamgage are referenced to North American Vertical Datum of 1988 (NAVD 88). The water-surface elevations for the Middle Fork Saline River near Harrisburg streamgage are referenced to National Geodetic Vertical Datum of 1929 (NGVD 29). The NGVD 29 elevations may be converted to NAVD 88 elevations at this site by subtracting $0.325 \mathrm{ft}$. In addition to the continuous measurements, some discrete discharge measurements were made at these sites during periods of moderate to high flow.

\section{Topographic/Bathymetric Data}

The 1/3-Arc Second National Elevation Dataset (NED) for the study area was downloaded from http://seamless.usgs. gov/. NED has a horizontal resolution of approximately $10 \mathrm{~m}$ and a vertical accuracy of approximately $2.44 \mathrm{~m}$ (Gesch, 2007) and was typically derived from cartographic contours and mapped hydrography. The NED does not contain detailed bathymetric data for the Middle Fork Saline River. Bathymetric and cross-sectional survey data were collected on the Middle Fork Saline River during September through November 2011. These survey data contain detailed channel elevation data below the water surface and were collected by using a

Table 1. U.S. Geological Survey streamgage information for the Ohio River at Old Shawneetown, Illinois-Kentucky, and the Middle Fork Saline River near Harrisburg, Illinois.

[mi², square miles; ft, feet; NAVD 88, North American Vertical Datum of 1988]

\begin{tabular}{|c|c|c|c|c|c|c|}
\hline Station name & Station number & $\begin{array}{c}\text { Drainage area } \\
\qquad\left(\mathrm{mi}^{2}\right)\end{array}$ & $\begin{array}{l}\text { Latitude } \\
\text { (degrees, minutes, } \\
\text { seconds) }\end{array}$ & $\begin{array}{c}\text { Longitude } \\
\text { (degrees, minutes, } \\
\text { seconds) }\end{array}$ & $\begin{array}{l}\text { Period } \\
\text { of record }\end{array}$ & $\begin{array}{l}\text { Maximum } \\
\text { recorded elevation } \\
\text { at gage ( } f \text { above } \\
\text { NAVD } 88 \text { ) and date }\end{array}$ \\
\hline
\end{tabular}


SonarMite echosounder (Ohmex Instrumentation, 2012) for the bathymetry and a total-station surveying instrument for elevations above the water surface. These survey data were to be included in a hydraulic model of the Middle Fork Saline River before the analysis of the streamgage record showed that backwater from the Ohio River dominates the streamgage near Harrisburg and creates non-unique stage-discharge relations, making steady-state, one-dimensional hydraulic modeling insufficient.

\section{Development of Inundation Surfaces}

Inundation maps were developed for a total of eight gage heights at 5 -ft intervals. The gage heights ranged from $31 \mathrm{ft}$ to $66 \mathrm{ft}$ as referenced to the Ohio River at Old Shawneetown, Ill.-Ky., streamgage (03381700). The low end of this range of gage heights is just above the NWS Action Stage, and the high end is slightly above the maximum historical gage height value (National Weather Service, 2012). The method for creating the eight inundation surfaces was based on the Ohio River backwater controlling the Middle Fork Saline River watersurface elevations. To estimate the water-surface elevations to be mapped, the streamgage at Old Shawneetown (03381700) was used as the reference elevation. To estimate the change in the water-surface elevation away from the streamgage, the slope of the Ohio River water-surface elevation was determined from a HEC-2 model provided by the U.S. Army Corps of Engineers (Ken Lamkin, U.S. Army Corps of Engineers, Louisville District, written commun., 2011). From that model, elevations of the Ohio River at the confluence with the Wabash River (upstream of the streamgage) and at the confluence with the Saline River (downstream of the streamgage) could be related to the elevation at the streamgage (table 2).

Table 2. Relative elevations of the Ohio River at Old Shawneetown USGS streamgage, Ohio-Saline confluence, and Ohio-Wabash confluence.

[WSE, water-surface elevation; ft, feet; NAVD 88, North American Vertical Datum of 1988]

\begin{tabular}{ccc}
\hline $\begin{array}{c}\text { WSE at } \\
\text { Shawneetown } \\
\text { (ft above NAVD 88) }\end{array}$ & $\begin{array}{c}\text { Corresponding } \\
\text { WSE at Ohio-Saline } \\
\text { confluence }\end{array}$ & $\begin{array}{c}\text { Corresponding WSE } \\
\text { at Ohio-Wabash } \\
\text { confluence }\end{array}$ \\
\hline 340 & 336.46 & 342.59 \\
345 & 341.70 & 347.37 \\
350 & 346.95 & 352.16 \\
355 & 352.19 & 356.94 \\
360 & 357.43 & 361.73 \\
365 & 362.67 & 366.51 \\
370 & 367.91 & 371.30 \\
375 & 373.16 & 376.09 \\
\hline
\end{tabular}

As shown in figure 2, the area to be mapped was then divided according to Hydrologic Unit Code (HUC-12) basin boundaries. The majority of the area (Beaver Creek-Saline River group) is inundated with the water-surface elevation at the Saline-Ohio River confluence, one area (Sibley CreekOhio River group) is inundated with the elevation at the streamgage, one area (Willow Pond Slough-Wabash River) is inundated with the elevation at the Wabash-Ohio River confluence, and one special-case area (Cypress Ditch) uses the Saline-Ohio River confluence elevation for the lower elevations and the Wabash-Ohio River confluence elevation for the higher elevations. The special-case area of Cypress Ditch is where the Wabash River partially flows into the Saline River instead of completely draining to the Ohio River.

\section{Inundation Mapping}

Flood-inundation maps were developed for eight watersurface elevations corresponding to the gage heights observed at the Ohio River at Old Shawneetown, Ill.-Ky., streamgage. The maps were created in ArcMap (Esri, Inc., 2012) by combining the water-surface elevations and Digital Elevation Model (DEM) data. Estimated flood-inundation boundaries for each water-surface elevation were created by using a DEM with a $10-\mathrm{m}$ (approximately $30-\mathrm{ft}$ ) cell size. The inundation surface was then created by subtracting the ground-surface DEM from the water-elevation surface. The maps show estimated flood-inundated areas overlaid on high-resolution, georeferenced aerial photographs of the study area for each of the generated inundation surfaces for every $5 \mathrm{ft}$ of change in gage height ranging from 31 to $66 \mathrm{ft}$.

\section{Inundation Verification}

The inundation surfaces produced with this method were compared to Landsat satellite imagery taken during selected flood events in spring 2011 (U.S. Geological Survey, 2011). Three different water-surface elevations at the Old Shawneetown streamgage $(350.1 \mathrm{ft}$ on April 17, 2011, $357.6 \mathrm{ft}$ on March 16, 2011, and $364.7 \mathrm{ft}$ on May 3, 2011) were compared to inundation surfaces produced for water-surface elevations of $350 \mathrm{ft}, 355 \mathrm{ft}$, and $365 \mathrm{ft}$, respectively. The comparisons show that the generated inundation surfaces do a reasonable job in approximating the inundated area portrayed in the satellite images (fig. $3 A-C$ ). 


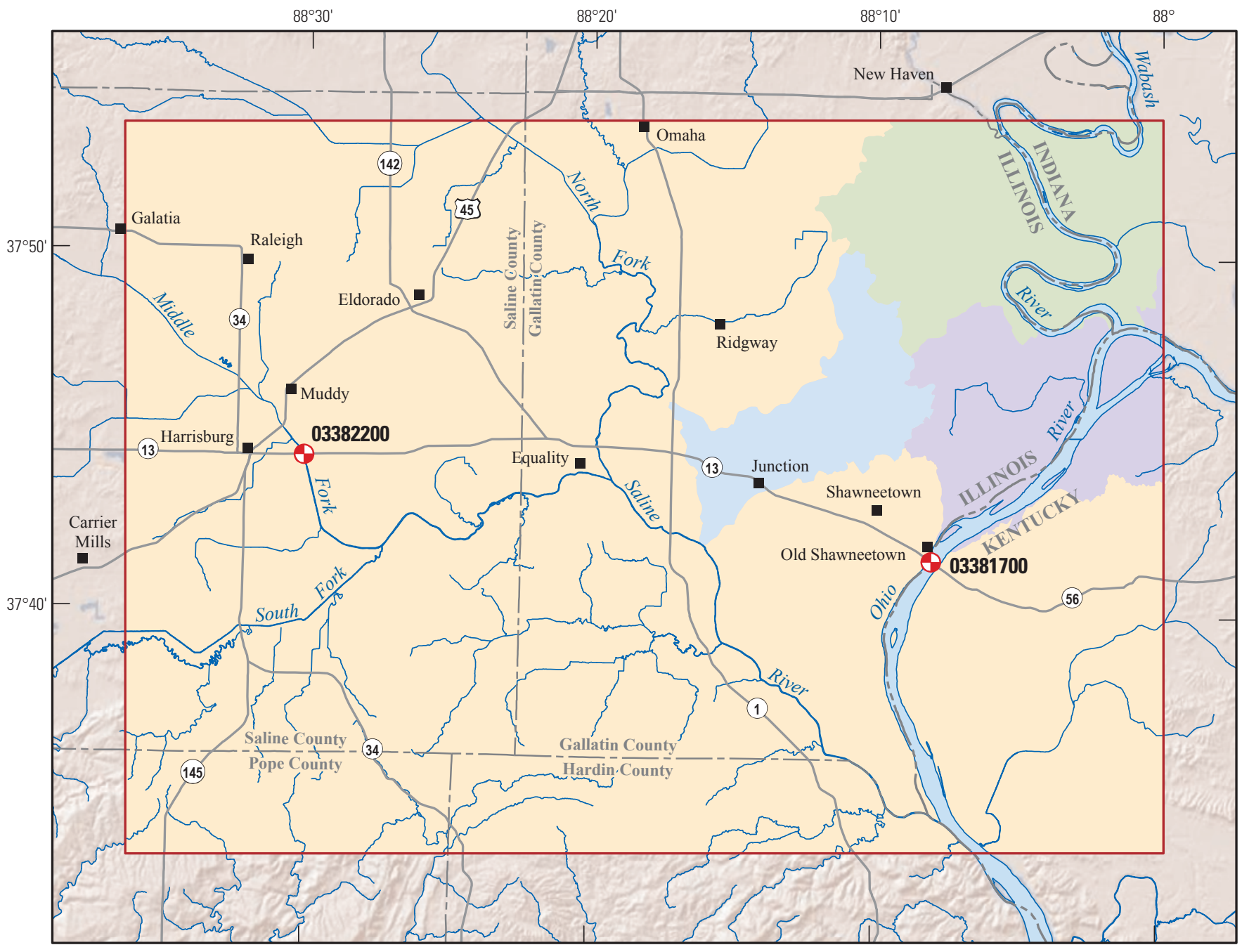

Map base from ArcGIS Map Service World_Shaded_Relief, accessed May 2012 at http://services.arcgisonline.com/arcgis/services

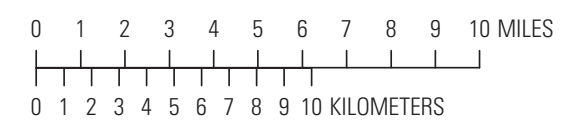

\section{EXPLANATION}

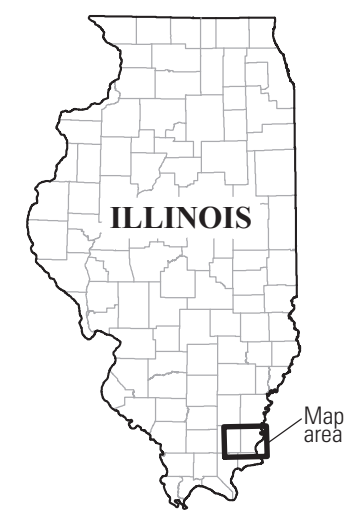

Grouped HUC12 basins

Beaver Creek-Saline River

Cypress Ditch

Sibley Creek-Ohio River

Willow Pond Slough-Wabash River

\section{Saline and Wabash Rivers study}

USGS streamgage and number

Figure 2. Map showing the grouped Hydrologic Unit Code (HUC-12) basins with common water-surface elevations assigned for inundation-surface generation. 


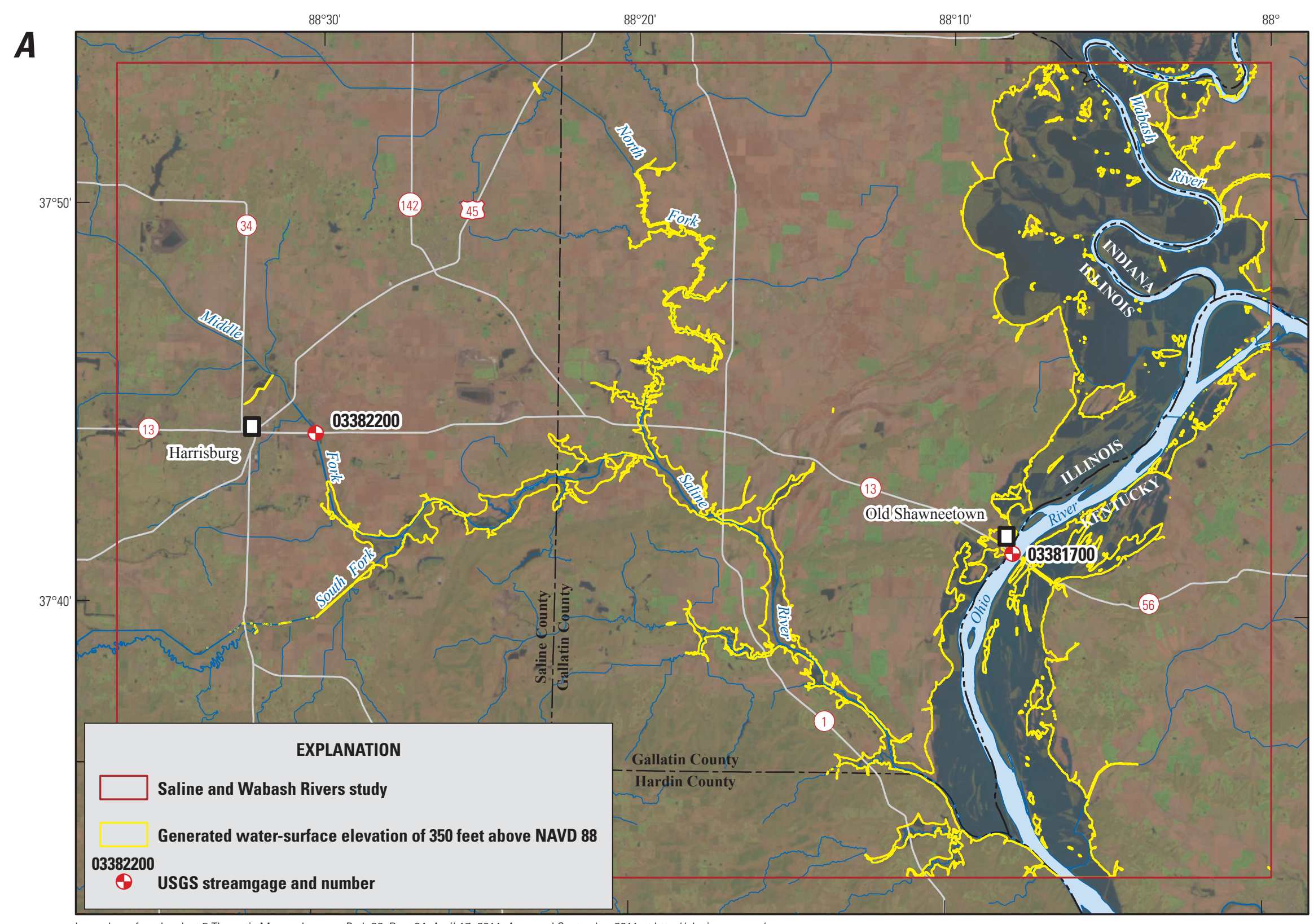

Image base from Landsat 5 Thematic Mapper Imagery, Path 22, Row 34, April 17, 2011. Accessed September 2011 at http://glovis.usgs.gov/.

Figure $\mathbf{3} \boldsymbol{A}$. Map showing generated water-surface elevations as compared to satellite imagery of flooding. Dark blue areas on the Thematic Mapper imagery represent inundated areas. 350 feet compared to flooding on April 17, 2011, with a water-surface elevation of 350.1 feet at the streamgage. 


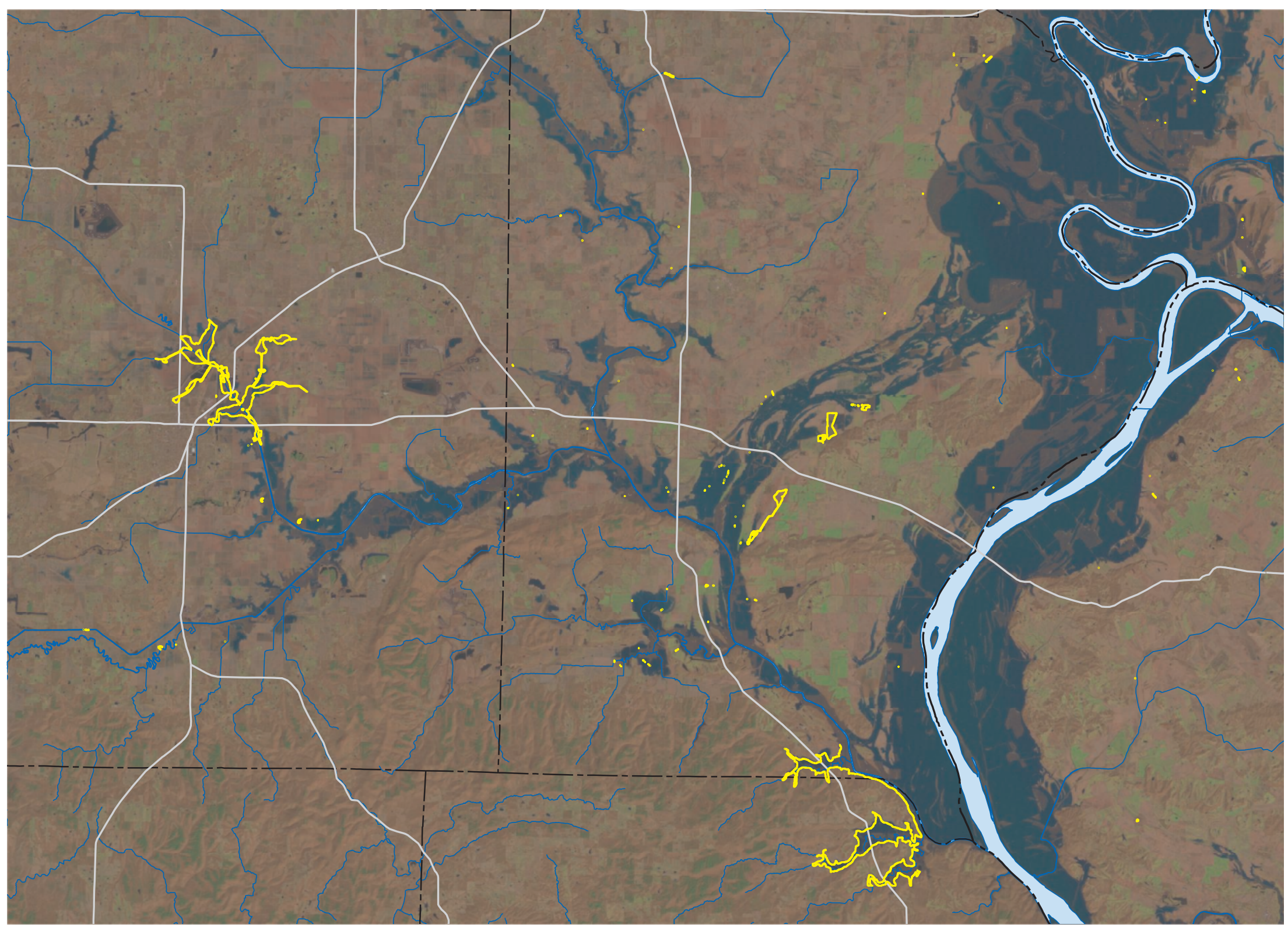

$\infty$

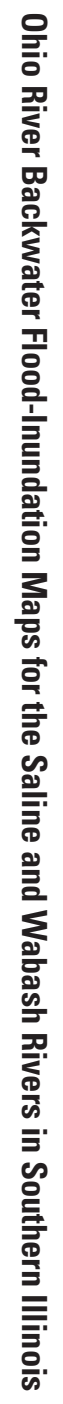




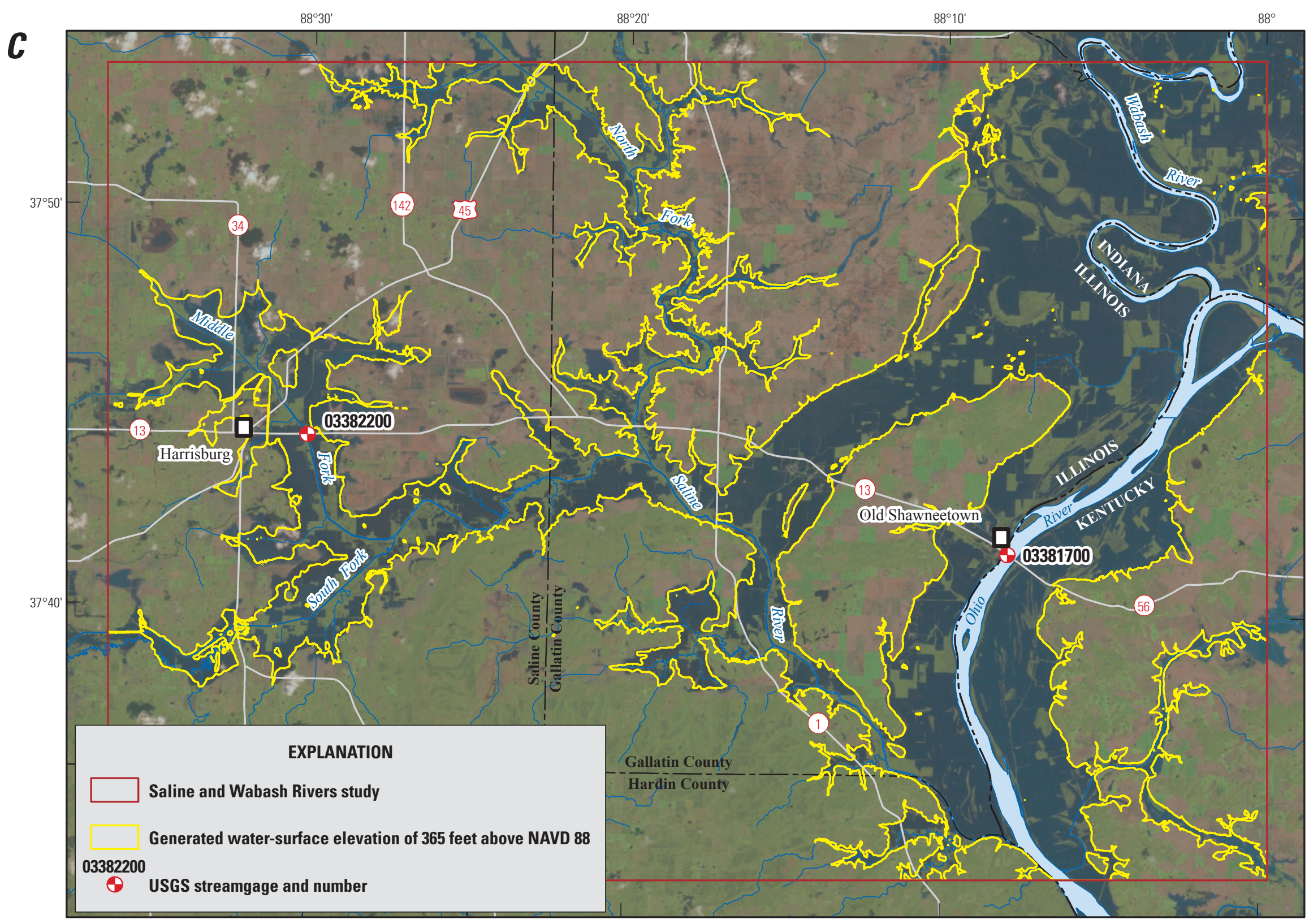

Image base from Landsat 5 Thematic Mapper Imagery, Path 22, Row 34, May 3, 2011. Accessed September 2011 at http://glovis.usgs.gov/.

Figure 3C. Map showing generated water-surface elevations as compared to satellite imagery of flooding. Dark blue areas on the Thematic Mapper imagery represent inundated areas. 355 feet as compared to flooding on March 16, 2011, with a water-surface elevation of 357.6 feet at the streamgage. 


\section{USGS Flood-Inundation Maps on the Internet}

A USGS Flood Inundation Mapping Science World Wide Web portal has been established at URL http://water.usgs.gov/ osw/flood inundation/to provide estimated flood-inundation information to the public. The maps from this study showing the extent of inundated areas can be downloaded in three electronic file formats from that portal: (1) GIS shapefile format, (2) KMZ file format, and (3) Portable Document Format (PDF). Users can print out formatted maps (recommended size for printing is $11 \times 17$ in) or create customized maps using available GIS data layers. Each stream reach displayed on the Web site contains links to NWISWeb graphs of the current stage and streamflow at USGS streamgage Ohio River at Old Shawneetown, Ill.-Ky. (to which the inundation maps are referenced) and Middle Fork Saline River near Harrisburg, Ill. (which is at the upstream end of the study reach). A link also is provided to the NWS Advanced Hydrologic Prediction Service (AHPS) site (http://water.weather.gov/ahps/) so that the user can obtain applicable information on forecasted peak stage. The estimated flood-inundation maps are displayed in sufficient detail to note the extent of flooding with respect to individual structures so that preparations for flooding and decisions for emergency response can be performed efficiently, although the uncertainties and limitations described in this report must be considered.

\section{Disclaimer for Flood-Inundation Maps}

Inundated areas shown should not be used for navigation, regulatory, permitting, or other legal purposes. The USGS provides these maps "as-is" for a quick reference, emergency planning tool but assumes no legal liability or responsibility resulting from the use of this information.

\section{Uncertainties and Limitations Associated with Inundation Maps}

Although the flood-inundation maps represent the boundaries of inundated areas with a distinct line, some uncertainty is associated with these maps. The flood boundaries shown were estimated on the basis of gage heights (water-surface elevations) at a selected USGS streamgage. Water-surface elevations along the stream reaches were estimated by assuming unobstructed flow and using hydrologic conditions anticipated at the USGS streamgage. Unique meteorological factors (timing and distribution of precipitation) may cause actual water-surface elevations along the mapped reach to vary from those assumed during a flood, which may lead to deviations in the inundation boundaries shown. Additional areas may be flooded due to unanticipated conditions such as changes in the streambed elevation or roughness, or backwater from localized debris or ice jams. The accuracy of the floodwater extent portrayed on these maps will vary with the accuracy of the Digital Elevation Model used to simulate the land surface.
If this series of flood-inundation maps will be used in conjunction with National Weather Service (NWS) river forecasts, the user should be aware of additional uncertainties that may be inherent or factored into NWS forecast procedures. The NWS uses forecast models to estimate the quantity and timing of water flowing through selected stream reaches in the United States. These forecast models (1) estimate the amount of runoff generated by precipitation and snowmelt, (2) simulate the movement of floodwater as it proceeds downstream, and (3) predict the flow and stage (water-surface elevation) for the stream at a given location (AHPS forecast point) throughout the forecast period (every 6 hours and 3 to 5 days out in many locations). For more information on AHPS forecasts, please see: http://water.weather.gov/ahps/pcpn_and_river forecasting.pdf.

As mentioned previously, a USGS Flood Inundation Mapping Science World Wide Web portal has been established at URL http://water.usgs.gov/osw/flood_inundation/to provide estimated flood-inundation information to the public. Although USGS intends to make this server available 24 hours a day, 7 days a week, timely delivery of data and products from this server through the Internet is not guaranteed.

\section{Acknowledgments}

The authors wish to thank the many local, State, and Federal agencies that provided funding and cooperated in the operation and maintenance of the streamgages used for this study. Thanks are extended to Ken Lamkin and Richard Pruitt of the U.S. Army Corps of Engineers, Louisville District for providing the HEC-2 model of the Ohio River; Terry Ortel of the USGS Illinois Water Science Center (ILWSC) for Web-site support; and David Fazio and Charles Bohall of the USGS ILWSC for surveying work. Thanks are also extended to Robert R. Holmes, USGS Office of Surface Water, for his support of this project.

\section{Summary}

A series of estimated flood-inundation maps were developed for the Wabash and Saline Rivers in southern Illinois. These maps, available at URL (http://water.usgs.gov/osw/ flood_inundation/), in conjunction with the real-time gage height data from the USGS streamgage at the Ohio River at Old Shawneetown, Ill.-Ky.(station no. 03381700) and National Weather Service flood-stage forecasts, can help to guide the general public in taking individual safety precautions and can provide local government officials with a tool to efficiently manage emergency flood operations and flood mitigation efforts.

The maps were developed by using ArcMap to delineate estimated flood-inundation areas for selected gage heights. The maps show estimated flood-inundation areas overlaid on 
high-resolution, georeferenced aerial photographs of the study area for gage heights between $31 \mathrm{ft}$ and $66 \mathrm{ft}$ at the Ohio River at Old Shawneetown streamgage.

\section{References Cited}

Esri, Inc., 2012, ArcGIS Desktop-Release 10.0: Redlands, Calif.

Federal Emergency Management Agency, 2009, Illinois Severe Storms and Flooding, Disaster Summary for FEMADR-1850, Illinois: Accessed April 17, 2012, at http://www. fema.gov/news/eventcounties.fema? id $=11668$.

Federal Emergency Management Agency, 2011a, Flood Insurance Study, Saline County, Illinois and Incorporated Areas: Flood Insurance Study Number 17165CV000A [variously paginated].

Federal Emergency Management Agency, 2011b, Flood Insurance Study, Gallatin County, Illinois and Incorporated Areas: Flood Insurance Study Number 17059CV000A [variously paginated].

Federal Emergency Management Agency, 2011c, Illinois Severe Storms and Flooding, Disaster Summary for FEMA-DR-1991, Illinois: Accessed April 17, 2012, at http://www.fema.gov/news/eventcounties.fema? $\mathrm{id}=14672$.

Gesch, D.B., 2007, The National Elevation Dataset, chap. 4 of Maune, D., ed., Digital elevation model technologies and applications - The DEM users manual (2d ed.): Bethesda, Md., American Society for Photogrammetry and Remote Sensing, p. 99-118.

Illinois State Geological Survey, 2012, Physiographic divisions of Illinois: Accessed July 20, 2012, at http://www.isgs. illinois.edu/maps-data-pub/publications/physio.shtml.

National Weather Service, 2012, Advanced Hydrologic Prediction Service, Ohio River at Shawneetown: Accessed April 17, 2012, at http://water.weather.gov/ahps2/ hydrograph.php? wfo= pah\&gage $=$ shni2.

Ohmex Instrumentation, 2012, SonarMite v3 Echo Sounder: Accessed July 18, 2012, at http://www.ohmex.com/ sonarmite.html.

U.S. Census Bureau, 2012a, Saline County QuickFacts: Accessed April 16, 2012, at http://quickfacts.census.gov/ qfd/states/17/17165.html.
U.S. Census Bureau, 2012b, Gallatin County QuickFacts: Accessed July 20, 2012, at http://quickfacts.census.gov/qfd/ states/17/17059.html.

U.S. Geological Survey, 2011, USGS Global Visualization Viewer: U.S. Geological Survey, Earth Resources Observation and Science Center, accessed September 19, 2011, at http://glovis.usgs.gov/.

U.S. Geological Survey, 2012, National Water Information System-Web Interface, USGS 03381700 Ohio River at Old Shawneetown, Ill.-Ky.: Accessed April 16, 2012, at http://waterdata.usgs.gov/il/nwis/uv/?site no $=03381700 \&$ PARAmeter $c d=00065,00060$.

\section{Glossary}

DEM A Digital Elevation Model (DEM) is a digital file consisting of terrain elevations for ground positions at regularly spaced horizontal intervals.

Gage height Gage height is the term used by the USGS National Water Information System display to describe the height of water above the datum at a streamgage. It is synonymous with stage.

HUC A hydrologic unit code (HUC) is an identifier for a drainage basin.

Inundation surface The mathematical difference between the water-elevation surface and ground-elevation surface results in the inundation surface representing the area covered by water.

Rating curve A rating curve is the relation between stage and discharge at a cross-section in a river.

Stage Stage is the term used by the National Weather Service to describe the height of water above the datum at a streamgage. It is synonymous with gage height.

Water-surface elevation Water-surface elevation at a streamgage is determined by adding the gage height of the water to the datum for the streamgage. 


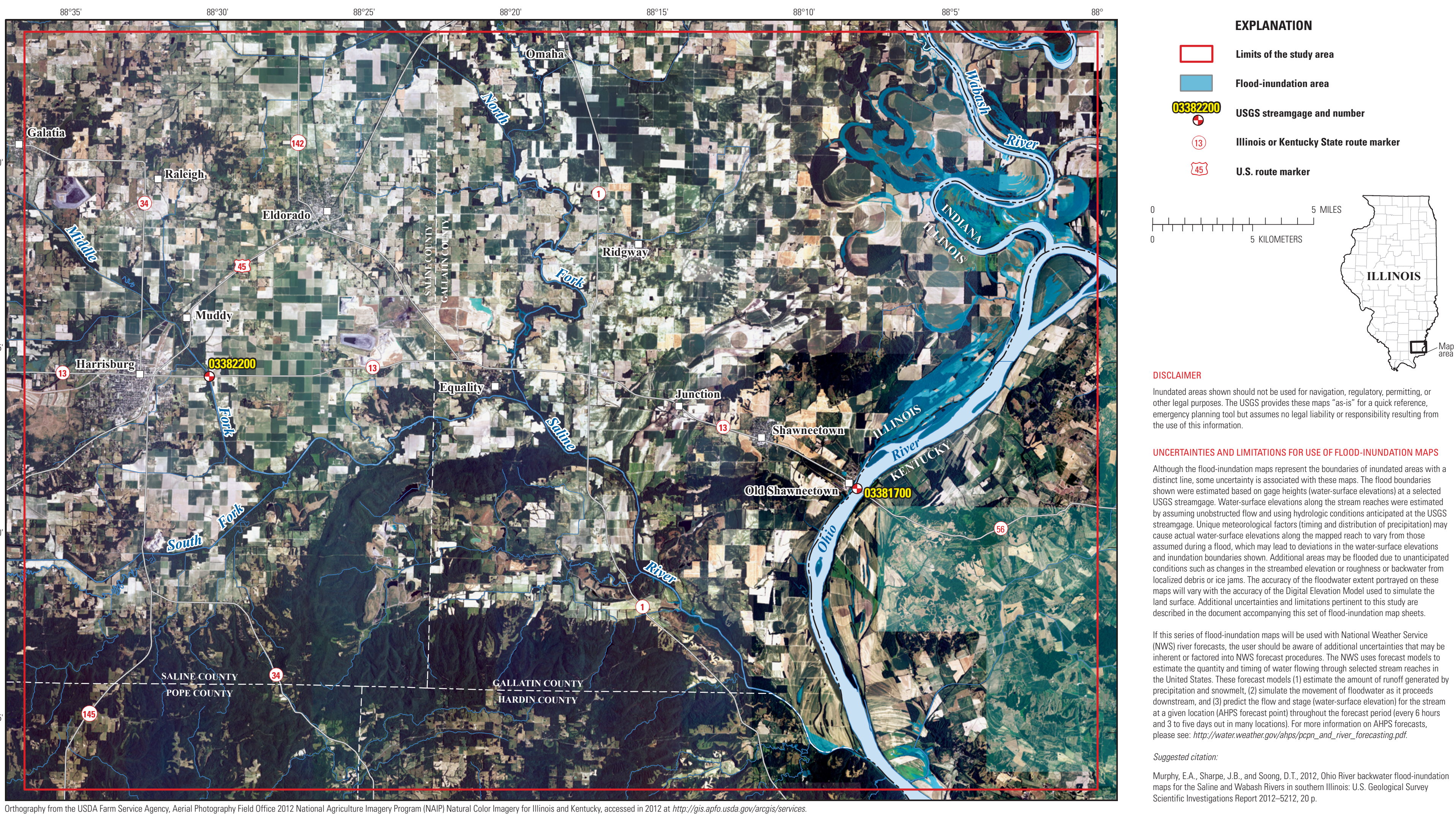


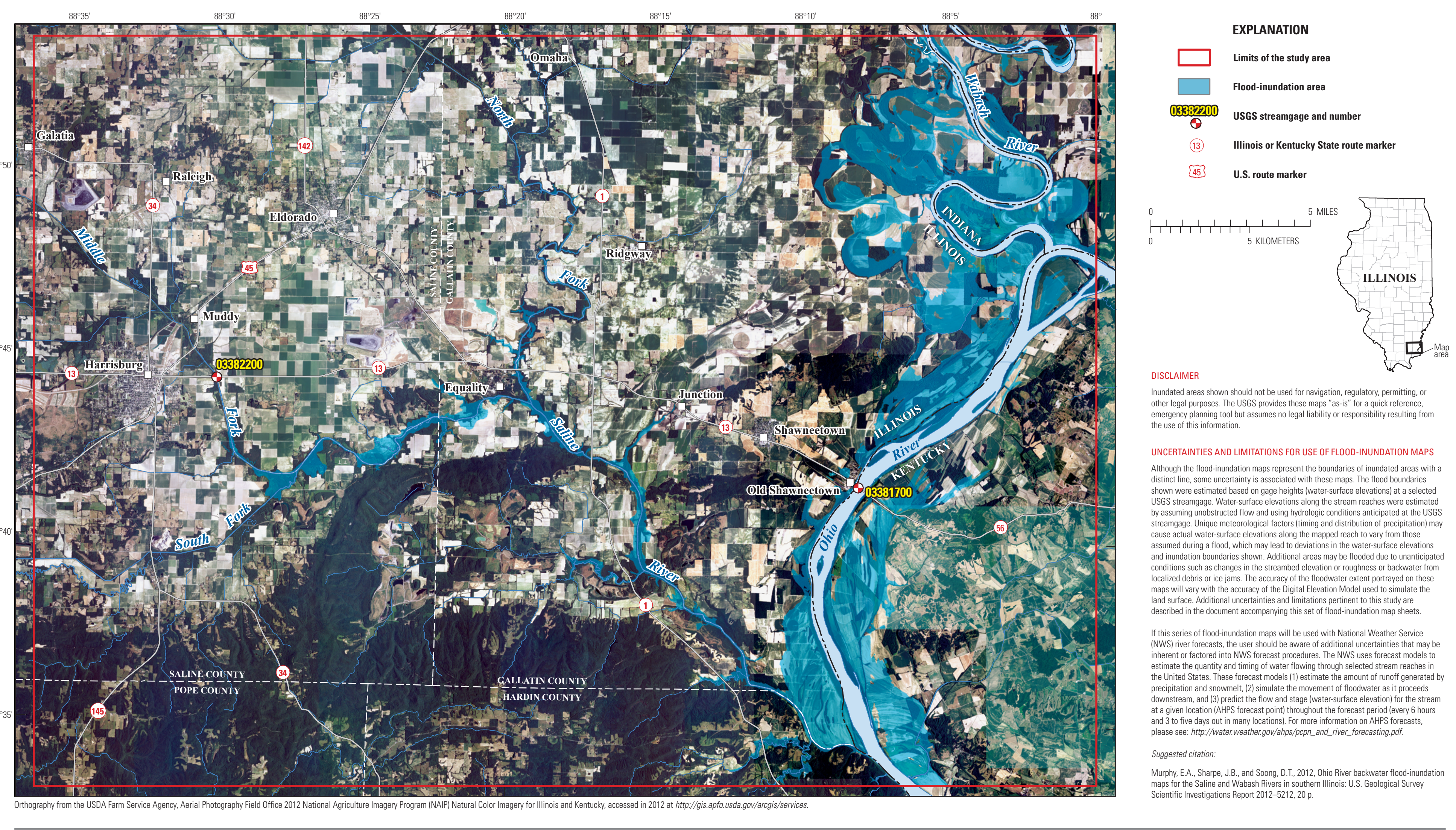

Sheet 2. Flood inundation map of the Saline and Wabash Rivers, Illinois, corresponding to a gage height of 36 feet at U.S. Geological Survey streamgage number 03381700, Ohio River at Old Shawneetown, Illinois-Kentucky. 

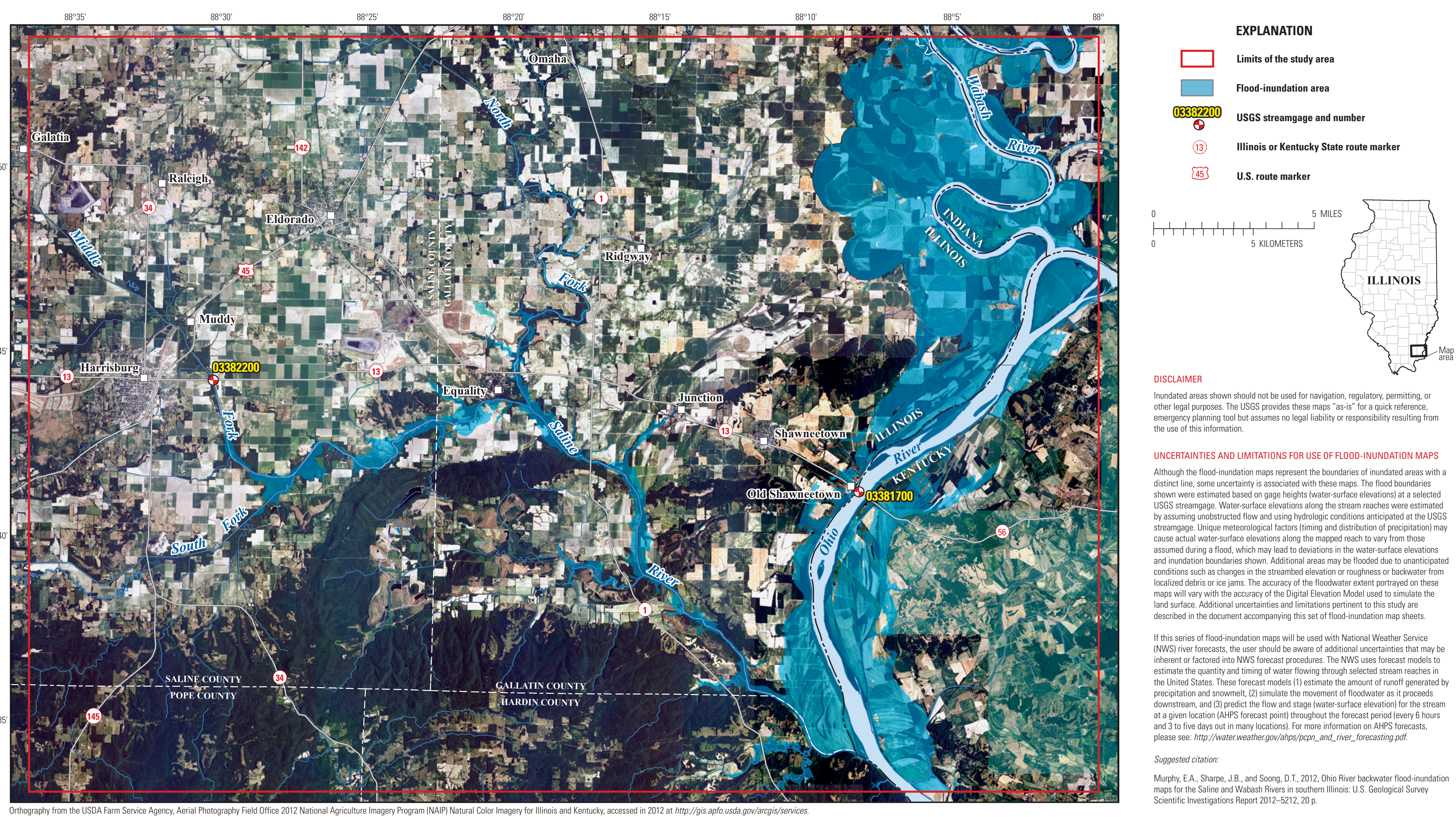

Sheet 3. Flood-inundation map of the Saline and Wabash Rivers, Illinois, corresponding to a gage height of 41 feet at U.S. Geological Survey streamgage number 03381700, Ohio River at Old Shawneetown, Illinois-Kentucky. 

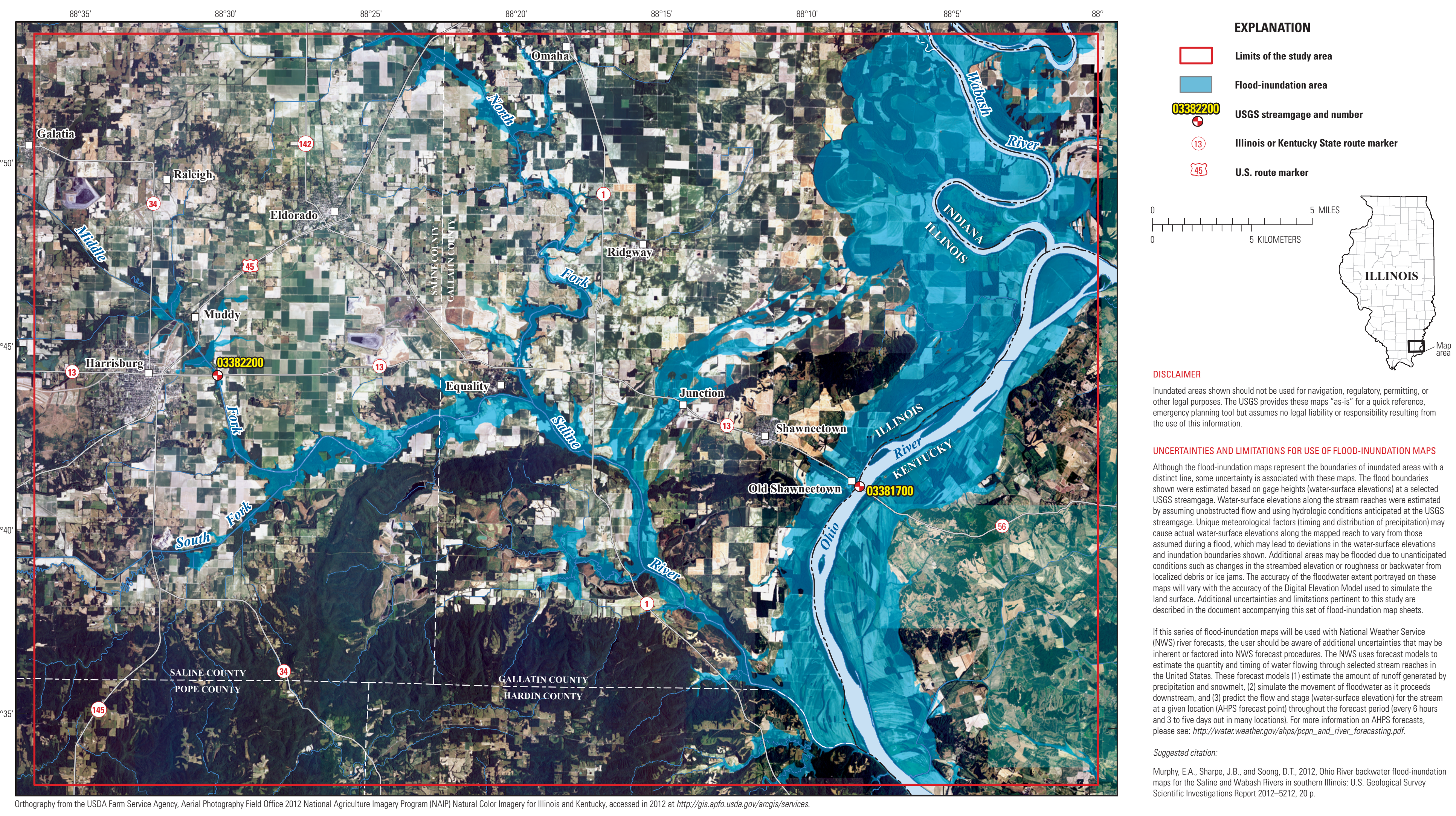

Sheet 4. Flood-inundation map of the Saline and Wabash Rivers, Illinois, corresponding to a gage height of 46 feet at U.S. Geological Survey streamgage number 03381700, Ohio River at Old Shawneetown, Illinois-Kentucky. 

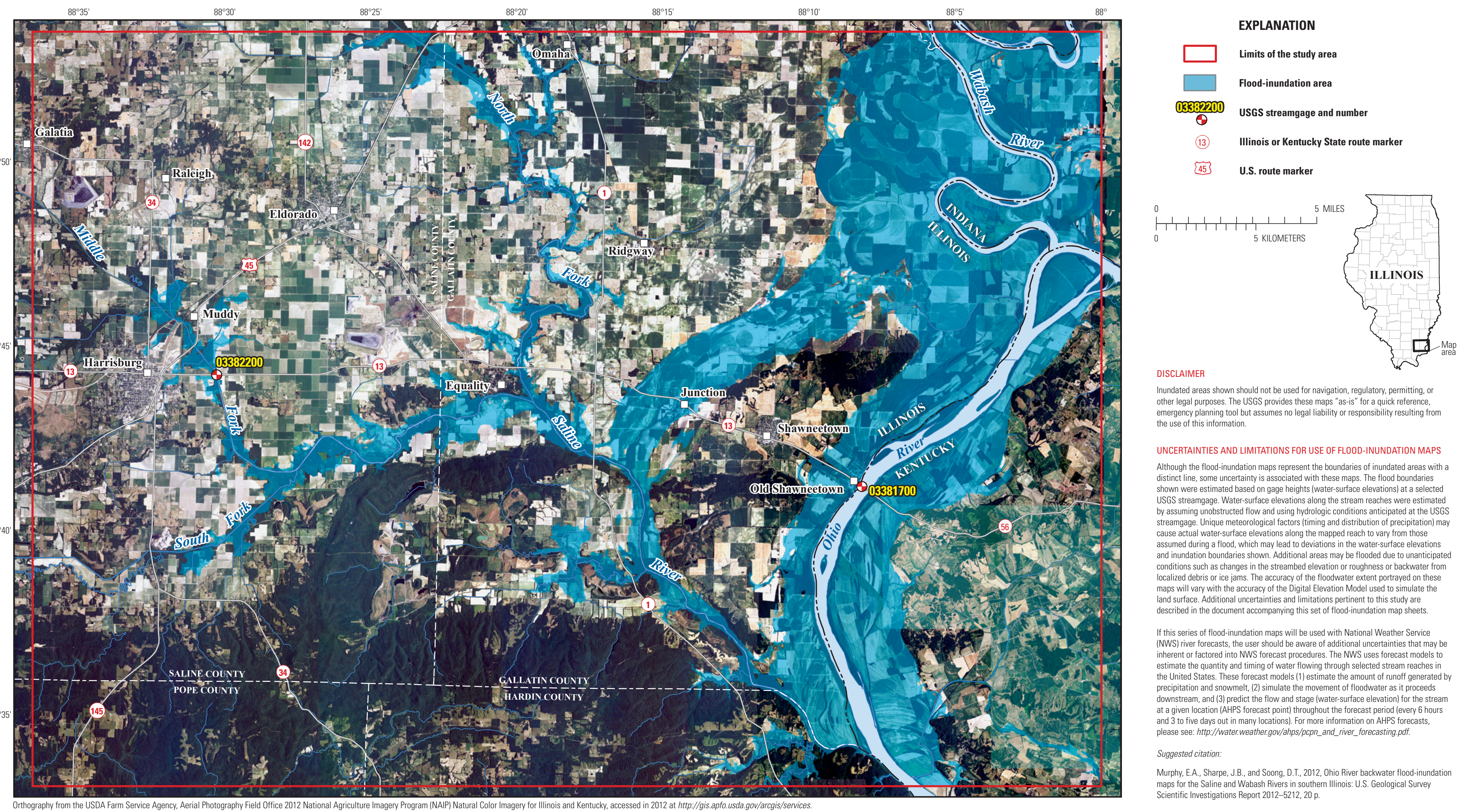

Sheet 5. Flood-inundation map of the Saline and Wabash Rivers, Illinois, corresponding to a gage height of 51 feet at U.S. Geological Survey streamgage number 03381700, 0hio River at 0ld Shawneetown, Illinois-Kentucky. 

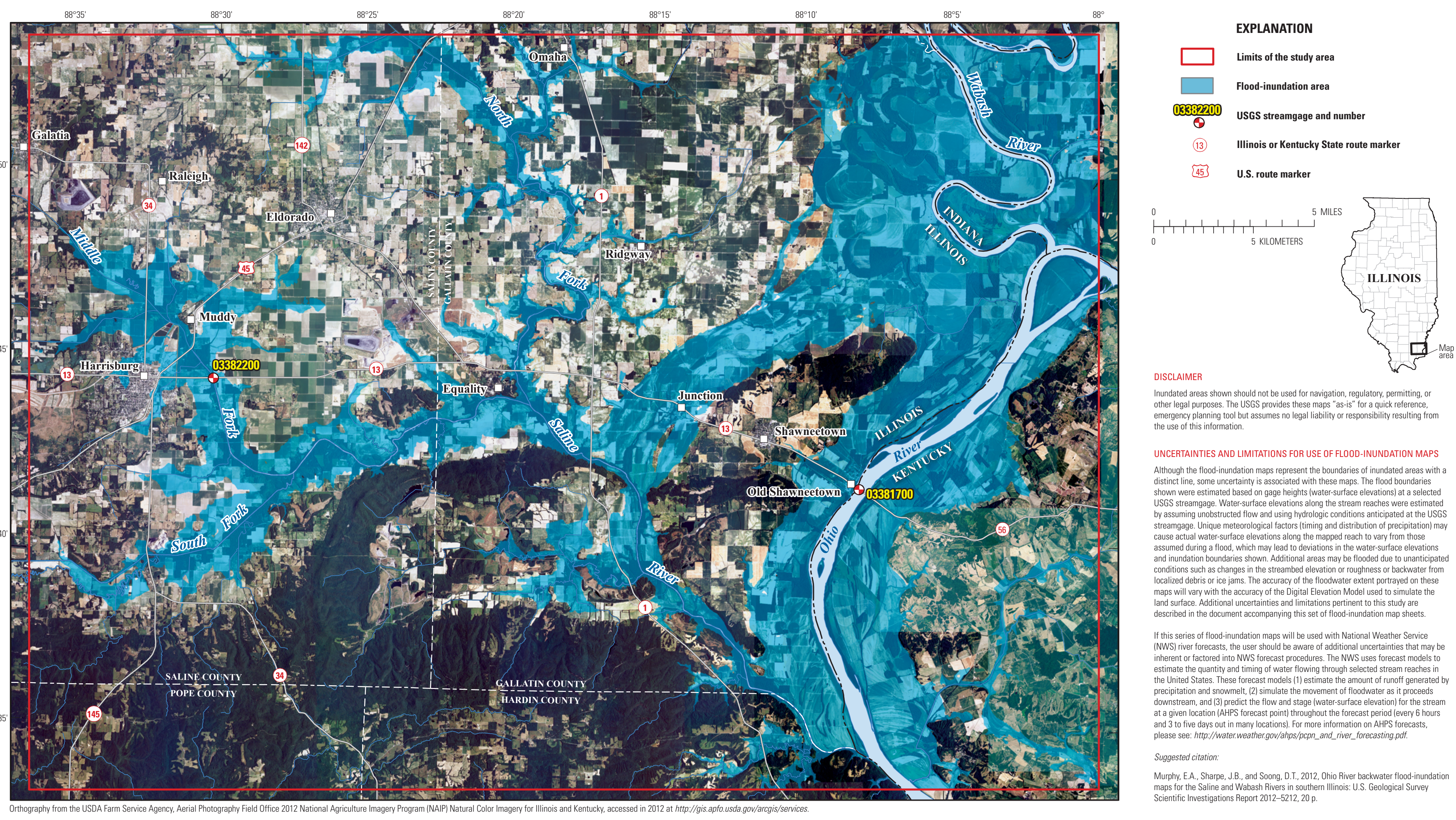

Sheet 6. Flood-inundation map of the Saline and Wabash Rivers, Illinois, corresponding to a gage height of 56 feet at U.S. Geological Survey streamgage number 03381700, Ohio River at 0ld Shawneetown, Illinois-Kentucky. 

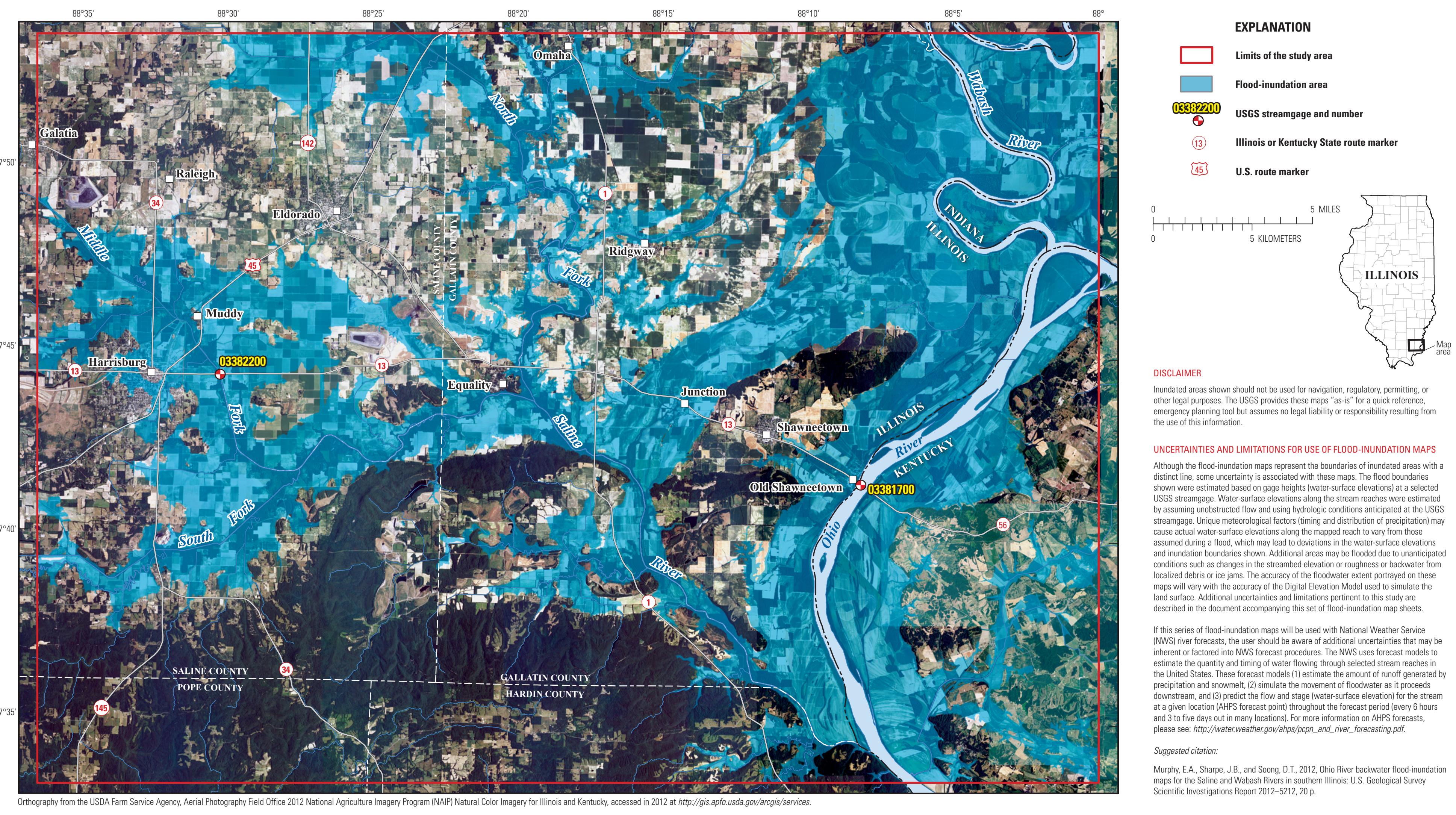

Sheet 7. Flood-inundation map of the Saline and Wabash Rivers, Illinois, corresponding to a gage height of 61 feet at U.S. Geological Survey streamgage number 03381700, Ohio River at Old Shawneetown, Illinois-Kentucky. 

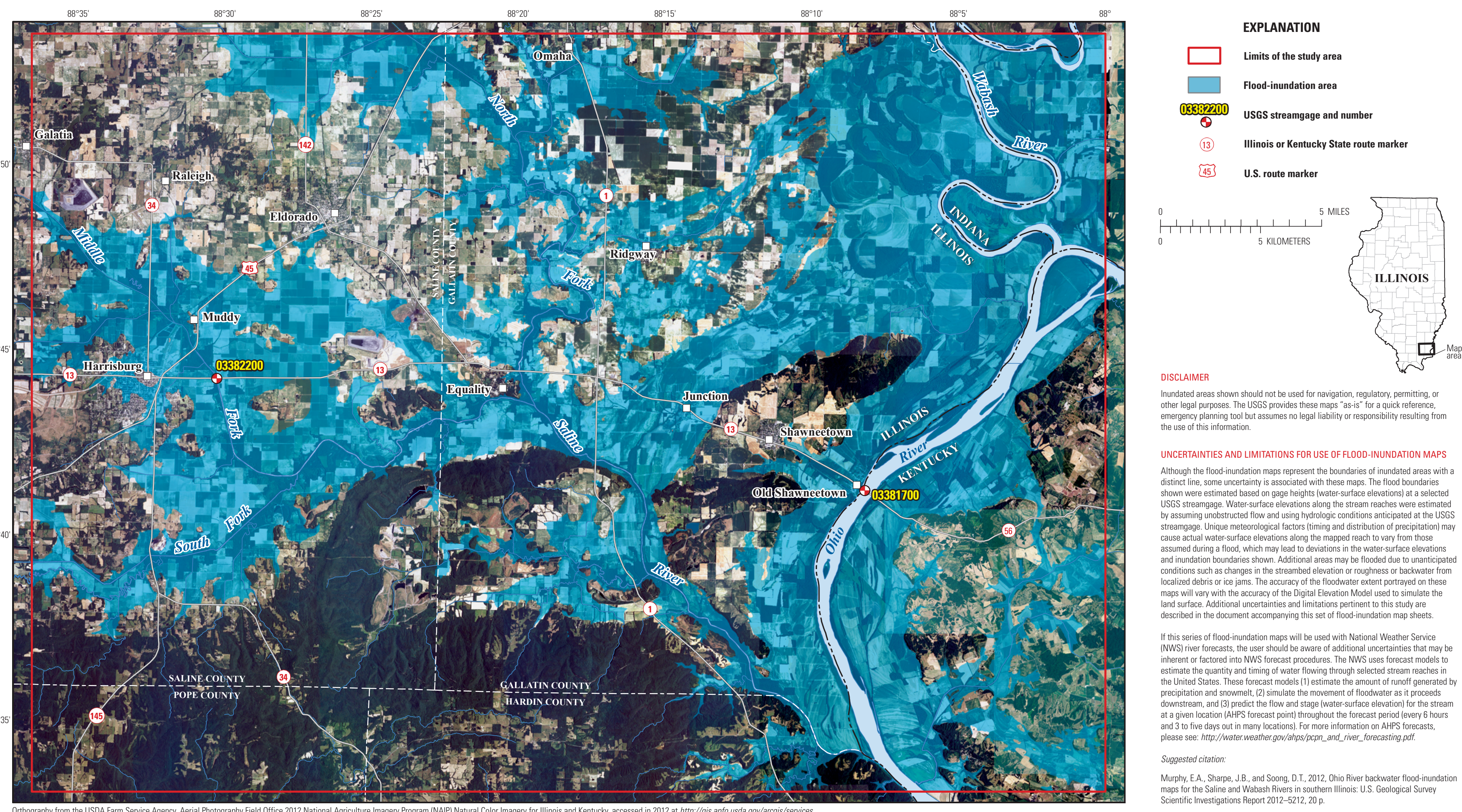

DISCLAIMER

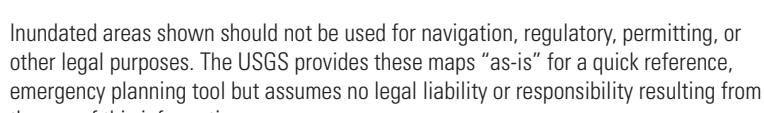
emergency planning tool but
the us o o fthis

UNCERTAINTIES AND LIMITATIONS FOR USE OF FLOOD-INUNDATION MAPS Athough the flood-inundation maps sepresent the boundaries 0 f inundated areas with a
distinct line, some uncertannty is associated with these maps. The flood boundaries

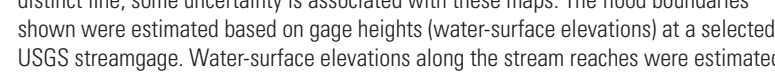

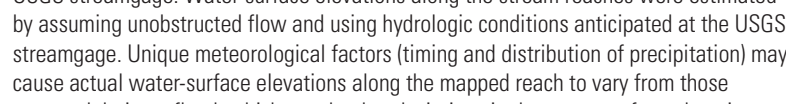

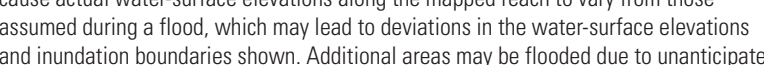

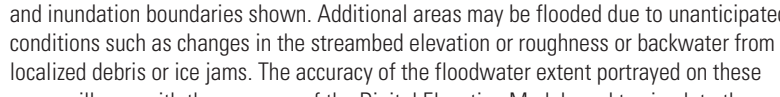

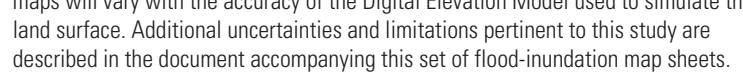
If this series of fllood-inundation maps will be used with National Weather Service
(NWSS river forceasts the user should be aware of additional uncertainties that may be

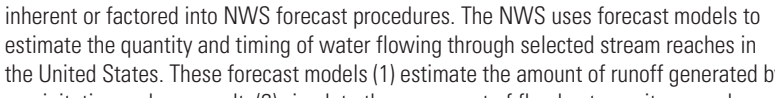

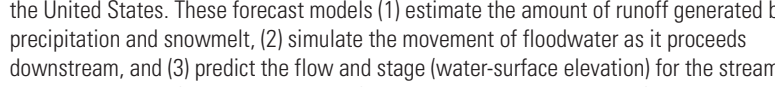
to g given Iocation (AAPS forecast point throughout the foreceast period (levery 6 hour

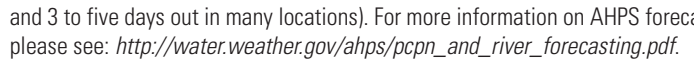
Suggested citation

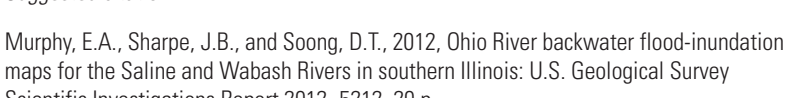
maps for the Saline and Wabash Rivers in soutt,
Scientific Investigations Report 2012-5212, 20 p.

Sheet 8. Flood-inundation map of the Saline and Wabash Rivers, Illinois, corresponding to a gage height of 66 feet at U.S. Geological Survey streamgage number 03381700, Ohio River at 0ld Shawneetown, Illinois-Kentucky. 



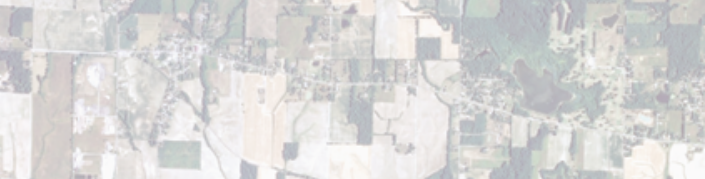

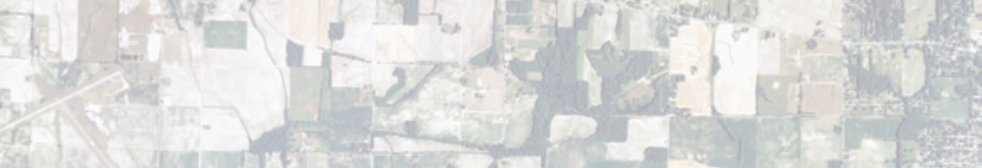

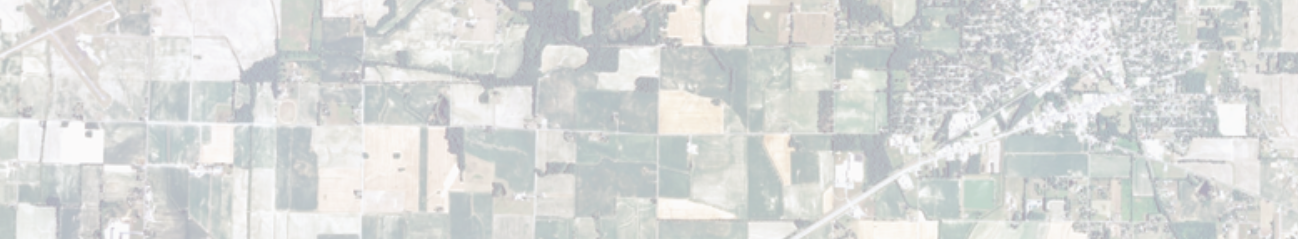

$\operatorname{lin}^{3}$

12.1

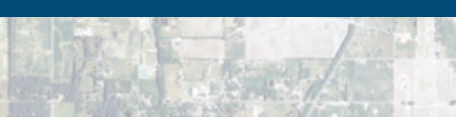

$\frac{1}{4}$

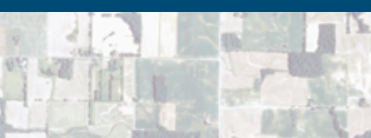

